\title{
Food and feeding habits of three main fish species in Lake Baringo, Kenya
}

\author{
Omondi, R. ${ }^{1 *}$, Yasindi A.W. ${ }^{2}$ and Magana A. M $^{3}$ \\ ${ }^{1}$ Kenya Marine and Fisheries Research Institute, P. O. Box 31 Kisumu, Kenya. \\ ${ }^{2}$ Department of Biological Sciences, Egerton University, P. O. Box 536, Egerton, Kenya. \\ ${ }^{3}$ Faculty of Science and Technology, Chuka University College, P.O. Box 109, Chuka, Kenya.
}

Accepted 7 August, 2013

\begin{abstract}
The diets of three fish species of commercial importance in Lake Baringo, Protopterus aethiopicus, Clarias gariepinus and Oreochromis niloticus, were determined using frequency of occurrence and volumetric methods between April 2008 and March 2010. Seine and gill nets were used to catch a total of 430 fish specimens. The diet of $P$. aethiopicus was $94.3 \%$ molluscs with a frequency of occurrence of $\mathbf{9 8 . 6 \%}$ of stomachs with food. Adult C. gariepinus fed mainly on fish with $75 \%$ of the stomachs with food containing fish remains and mean of $49.2 \%$ contribution by volume. $C$. gariepinus also fed on zooplankton, especially the cladoceran Daphnia barbata. The food items in the stomachs of $O$. niloticus consisted mainly of algae, detritus and zooplankton. Algae was consumed by $\boldsymbol{O}$. niloticus of all length classes in proportions ranging from 26.5 to $88.1 \%$. The importance of zooplankton as food for 0 . niloticus decreased with size of fish. The study reveals the importance of zooplankton as food for 0 . niloticus and C. gariepinus in Lake Baringo. There is need to rehabilitate the catchment of Lake Baringo so as to improve the water quality thus improve productivity.
\end{abstract}

Key words: Diet, Omnivorous, Algae, zooplankton, food web.

\section{INTRODUCTION}

Lake Baringo lies in a closed drainage basin of the Kenyan East African Rift Valley system at an altitude of $965 \mathrm{~m}$ above sea level with a surface area of approximately $130 \mathrm{~km}^{2}$ and a mean depth of $3.5 \mathrm{~m}$. Besides being a source of fish, water for drinking, irrigation and transport, the lake is also a repository of fauna and flora biodiversity. The lake's water quality has deteriorated in the recent past mainly due to sedimentation from its catchment arising from poor agricultural practices, deforestion and overgrazing. Consequently, these have led to a decline in fish catches. Since the 1980s, frequent lake closures to fishing activities have not alleviated the problem.

The fish community of Lake Baringo comprises seven species. These include Aplocheliches sp, Barbus intermedius australis, B. lineomaculatus, Clarias gariepinus, Labeo cylindricus, Oreochromis niloticus baringoensis and Protopterus aethiopicus (Britton et al., 2006). Of these, four species, namely C. gariepinus, O. $n$. baringoensis and $P$. aethiopicus, are economically exploited. The fishery of the lake was once dominated by the endemic $O$. $n$. baringoensis but is presently dominated by $P$. aethiopicus, which was introduced in 1975. Annual catches of $O$. $n$. baringoensis exceeded $600 \mathrm{t}$ in the 1960s but this decreased to mean annual catches of below $12 \mathrm{t}$ in 2006 despite a prolonged period of fishery closure (Britton et al., 2006).

Lungfishes, Proptopterus spp have been classified as omnivores feeding mainly on fishes besides other items like insects, crustaceans, annelids, mollusks, fish, detritus 
and plant material (Corbet, 1961; Mlewa and Green, 2004; Oniye et al., 2006; Adeyemi et al., 2009). C. gariepinus is a benthopelagic fish which is known to be voracious with a wide range of diet (Yalcin et al., 2002). Fish has been reported to be the most important food item among other materials like insects, shrimps, snails, detritus and macrophytes (Skelton, 1993; Dadebo, 2000, 2009; Yalcin et al., 2001; El Gamal and Ismail, 2005; Potts et al., 2008; David et al., 2010). Earlier studies in various lakes showed that $O$. niloticus is capable of using a wide range of food resources including algae, detritus, higher plant material, chironomids, zooplankton and fish (Getabu, 1994; Njiru et al., 2004; Shalloof and Khalifa, 2009).

Studies on natural feeding of fish could provide useful information on the trophic relationships in aquatic ecosystems (Abdel-Aziz and Gharib, 2007), which could be used in formulating management strategy options in a multi species fishery. Pius and Benedicta (2002) also reported the use of stomach content in reducing intra and inter specific competition for ecological niche. Apart from studies on the feeding biology of the marble fish, $P$. aethiopicus and O. niloticus by Mlewa and Green (2004) and Busienei (2003), respectively, there has been no comprehensive investigation on the diet of fish species of commercial importance in Lake Baringo. This study investigated the diet and the trophic inter-relationships of $P$. aethiopicus, C. gariepinus and $O$. niloticus in Lake Baringo.

\section{MATERIALS AND METHODS}

\section{Study area}

Lake Baringo (Figure 1) is a freshwater lake in the eastern arm of the Great Rift Valley in Kenya. It is located between latitude $0^{\circ} 30^{\prime} \mathrm{N}$ and $0^{\circ} 45^{\prime} \mathrm{N}$ and longitude $36^{\circ} 00^{\prime} \mathrm{E}$ and $36^{\circ} 10^{\prime} \mathrm{E}$ and lies approximately $60 \mathrm{~km}$ north of the equator at an altitude of $975 \mathrm{~m}$ above sea level (Kallqvist, 1987). The lake has a surface area of approximately $130 \mathrm{~km}^{2}$ and a catchment of $6,820 \mathrm{~km}^{2}$. It has a mean depth of $3 \mathrm{~m}$ with the deepest point being about $7 \mathrm{~m}$ at high water levels.

Stratified random design was used in this study. The lake was divided into five different sectors, based on proximity to river mouths and based on this, stations S2, C2 and N2 lying on the S-N transects while C3, C2 and C1 lying on the E-W transects were chosen (Figure 1 and Table 1). Stations S2 and C3 have the influence of rivers Molo and Mukutan respectively. Station C2 is at the centre of the lake, $\mathrm{C} 1$ in the west adjacent to rocky shores while N2 lies in the north.

Fish was caught quarterly between April 2008 and March 2010 by seining in the lake using a $5 \mathrm{~mm}$ mesh size of $30 \mathrm{~m}$ in length and $2 \mathrm{~m}$ depth seine net. Gillnets of various meshes were also used especially for larger fish specimens. Captured fishes were sorted into different species, the total length of each fish was noted to the nearest centimetre and gut content was removed and preserved in $4 \%$ formaldehyde solution. For fishes less than $5 \mathrm{~cm}$ total length, however, whole specimens were preserved.

In the laboratory, the stomach contents were emptied into a Petri dish and each food item sorted under $\times 50$ magnification of a binocular microscope. The gut contents were analysed using two methods, frequency of occurrence and volumetric method based on Hynes (1950). In the frequency of occurrence method, the occurrence of food items was expressed as the percentage of the total number of stomach containing food while in volumetric method, percentage volume contribution of each food item was visually assessed relative to all of the food items present in the gut.

The contents were analysed separately for two length classes in $C$. gariepinus and six length classes for $O$. niloticus. Additionally, for stomachs with zooplankton, the percentage contribution of each species in the diet of $O$. niloticus was determined.

\section{RESULTS}

In this study, gut content of a total of 430 fishes were analysed. Of these, 142, 72 and 216 were $P$. aethiopicus, $C$. gariepinus and $O$. niloticus, respectively. The total length for the three fish species were in the range of, 17.3-97.5, 19.6-63.0 and 2.4-28.0 cm, respectively. Juveniles of $P$. aethiopicus and $C$. gariepinus were not obtained from the lake during the study.

The diet of $P$. aethiopicus was dominated by molluscs with a mean composition of $94.3 \%$ (Table 2) with a frequency of occurrence of $98.6 \%$ of stomachs with food. Fish was also an important component of the species stomach contents with a mean contribution of $4.9 \%$ and a frequency of occurrence of $39.4 \%$ of the stomachs with food. Other food items recorded included detritus (1.0\%), insects $(0.10 \%)$ and higher plant materials $(0.1 \%)$. Insects found in the stomachs were of the order Odonata while the higher plant materials belonged to the families Ceratophyllaceae and Poaceae.

The diet of $C$. gariepinus consisted of mainly fish, detritus and zooplankton (Table 3). Fish was the dominant prey item. The frequency of occurrence for the prey was $75 \%$ with a mean contribution of $49.2 \%$ by volume. The other important components of the diet of the species were detritus and zooplankton. This food items contributed 28.3 and $19.6 \%$ of the diet by volume, respectively. The numbers of zooplankton recorded in the stomachs were, however, high with the highest being 85,300 organisms in a stomach of a $43.5 \mathrm{~cm}$ fish. Higher plant materials were also recorded in the stomach, albeit in small proportions.

Among the zooplankton prey, C. gariepinus preferred the cladoceran $D$. barbata as its prey. The percentage contribution of the item in the $C$. gariepinus stomachs ranged from 33 to $94 \%$. Other zooplankton taxa in the diet included copepods (nauplii, adult cyclopoids and calanoids), cladocerans $D$. excisum, and Ceriodaphnia cornuta while Filinia opoliensis was the only rotifer recorded in the stomachs. The proportion of $D$. barbata in the diet of C. gariepinus above $40 \mathrm{~cm}$ in length was higher (96.1\%) compared to those in the fishes below 40 $\mathrm{cm}$ with a proportion of $30.5 \%$ of the diet by volume (Table 4).

The food items in the stomachs of $O$. niloticus consisted mainly of algae, detritus and zooplankton (Figure 2). Other stomach components were higher plant materials, 


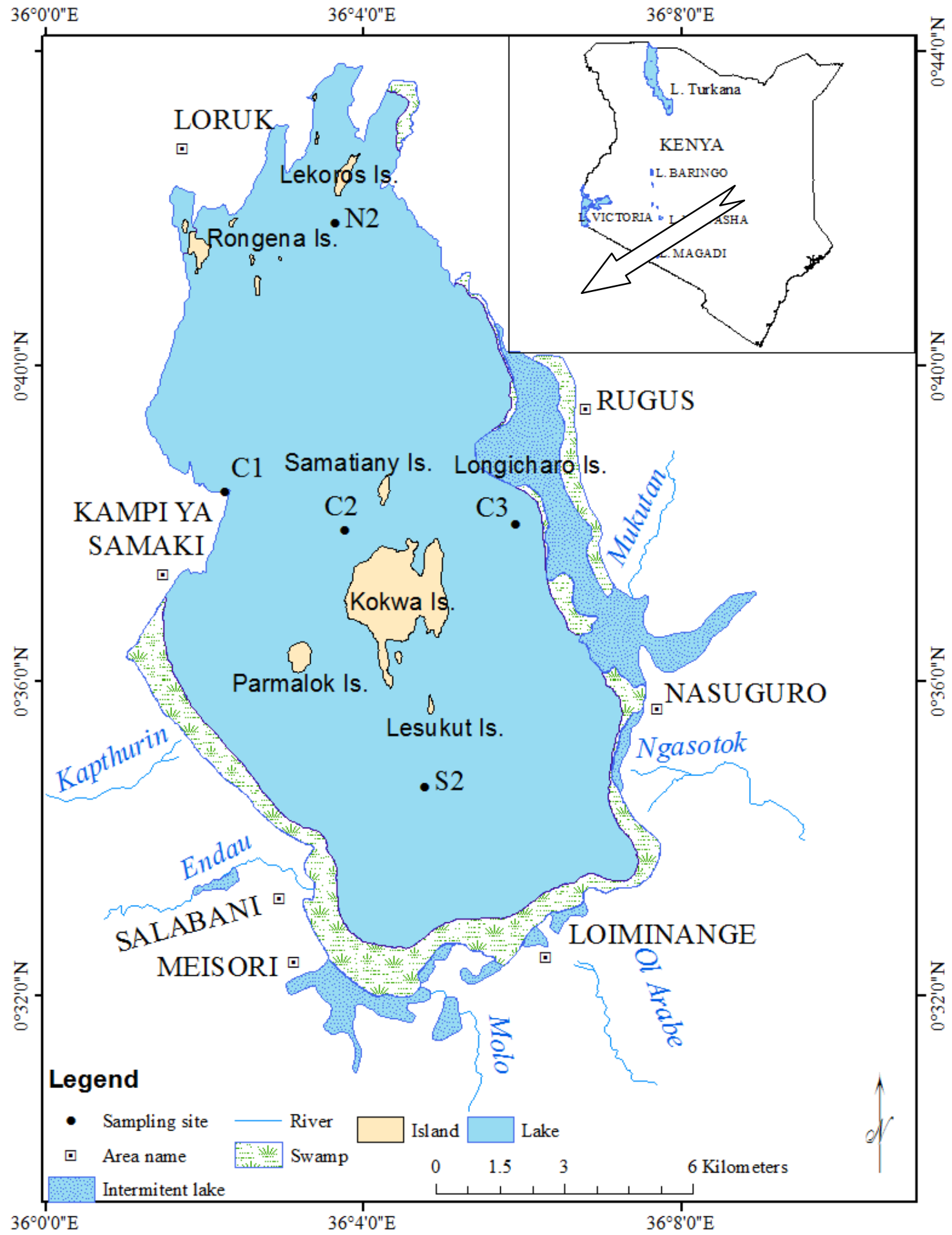

Figure 1. A map of Lake Baringo showing the sampling stations.

fish and insects. Algae were predominantly consumed by $O$. niloticus of all size classes in high proportions between 26.5 and $88.1 \%$ of the diet. While the importance of zooplankton decreased with size of fish, the reverse trend occurred for detritus with the proportion ingested increa- sing with size of niloticus. Insects, fish and higher plant materials on the other hand were hardly utilized by 0 . niloticus over $15 \mathrm{~cm}$ in length. The fish found in the few stomachs were probably accidentally swallowed by the mouth brooding females as all the stomachs where they 
Table 1. The geographical positions of the sampling stations in Lake Baringo.

\begin{tabular}{lrr}
\hline Station & \multicolumn{3}{c}{ Position } \\
\hline S2 & $00^{\circ} 34^{\prime} 38.7^{\prime \prime} \mathrm{N}$ & $036^{\circ} 04^{\prime} 47.3^{\prime \prime} \mathrm{E}$ \\
$\mathrm{C} 1$ & $00^{\circ} 38^{\prime} 13.0^{\prime \prime} \mathrm{N}$ & $036^{\circ} 02^{\prime} 42.1^{\prime \prime} \mathrm{E}$ \\
$\mathrm{C} 2$ & $00^{\circ} 38^{\prime} 0.1^{\prime \prime} \mathrm{N}$ & $036^{\circ} 03^{\prime} 53.2^{\prime \prime} \mathrm{E}$ \\
$\mathrm{C} 3$ & $00^{\circ} 37^{\prime} 59.0^{\prime \prime} \mathrm{N}$ & $036^{\circ} 05^{\prime} 54.4^{\prime \prime} \mathrm{E}$ \\
$\mathrm{N} 2$ & $00^{\circ} 41^{\prime} 33.4^{\prime \prime} \mathrm{N}$ & $036^{\circ} 03^{\prime} 27.2^{\prime \prime} \mathrm{E}$ \\
\hline
\end{tabular}

Table 2. Summary of the percentages of food items of $P$. aethiopicus in Lake Baringo.

\begin{tabular}{lcc}
\hline Parameter & Frequency of occurrence & Volume \\
\hline Insects & 2.8 & 0.10 \\
Molluscs & 98.6 & 94.29 \\
Fish remains & 39.4 & 4.88 \\
Detritus & 7.0 & 0.59 \\
Higher plant materials & 4.2 & 0.13 \\
\hline
\end{tabular}

Table 3. Summary of the percentages of food items of $C$. gariepinus in Lake Baringo.

\begin{tabular}{lll}
\hline Parameter & Frequency of occurrence & Volume \\
\hline Fish remains & 75 & 49.17 \\
Detritus & 75 & 28.33 \\
Plant materials & 50 & 2.92 \\
Zooplankton & 50 & 19.58 \\
\hline
\end{tabular}

Table 4. Percentage contribution of different prey items in the diet of different size classes of $C$. gariepinus in Lake Baringo during the study period.

\begin{tabular}{lcc}
\hline \multirow{2}{*}{ Parameter } & \multicolumn{2}{c}{ Size Class (cm) } \\
\cline { 2 - 3 } & $\mathbf{1 0 . 0}-\mathbf{3 9 . 9}$ & $\mathbf{4 0 . 0}-\mathbf{6 9 . 9}$ \\
\hline Nauplii & 27.1 & \\
Cyclopoida & 13.6 & 1.8 \\
Calanoida & & 1.5 \\
Diaphanosoma excisum & 27.1 & \\
Daphnia barbata & 30.5 & 96.1 \\
Others & 1.6 & 0.6 \\
\hline
\end{tabular}

occurred were females. Insects were found in only the stomachs of fishes in the size class of $5.0-9.9 \mathrm{~cm}$ with a proportion of $1.9 \%$ and these were terrestrial insects which could have been taken from the water surface.

Among the zooplankton species forming the main diet of $O$. niloticus are the cladocerans $D$. excisum, $M$. micrura and $D$. barbata. Important rotifer species were Brachionus patulus and Keratella tropica. The importance of copepods as food for the species was negligible as only nauplii were recorded in a few stomachs in low proportions. $M$. micrura and $D$. excisum were the dominant prey items ingested by fish less than $10 \mathrm{~cm}$ in length occurring in proportions of 13.8 to $66.5 \%$ in the stomachs of fishes below $10.0 \mathrm{~cm}$ respectively (Table 5). The two species were also found in the diet of the largest size class, $25.0-29.9 \mathrm{~cm}$, in the proportions of 72.0 and 


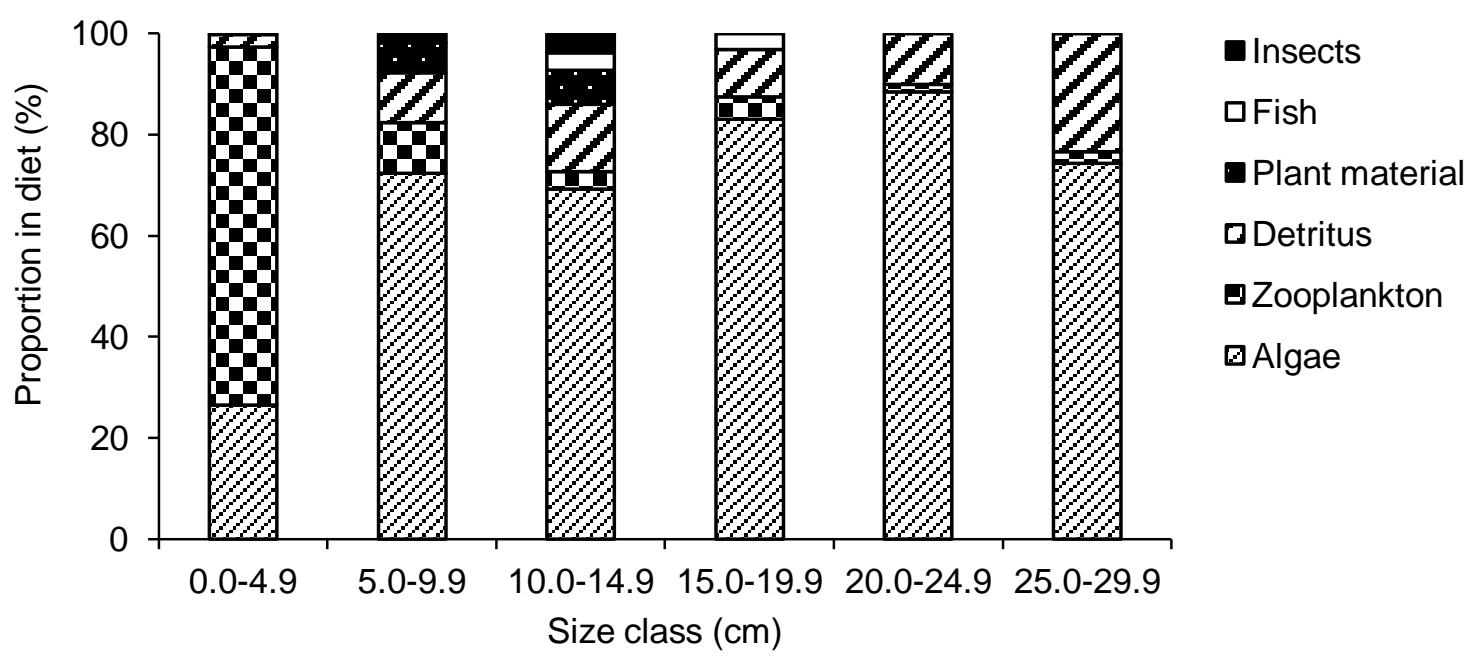

Figure 2. Diet composition of different size classes, by volume, of O. niloticus in Lake Baringo during the study period.

Table 5. Proportions of various zooplankton species in the diet of Oreochromis niloticus in Lake Baringo between April 2008 and March 2010.

\begin{tabular}{lcccccc}
\hline Parameter & \multicolumn{5}{c}{ Size classes (TL cm) } \\
\cline { 2 - 7 } & $\mathbf{2 . 4 - 4 . 9}$ & $\mathbf{5 . 0 - 9 . 9}$ & $\mathbf{1 0 . 0 - 1 4 . 9}$ & $\mathbf{1 5 . 0 - 1 9 . 9}$ & $\mathbf{2 0 . 0 - 2 4 . 9}$ & $\mathbf{2 5 . 0 - 2 9 . 9}$ \\
\hline Moina micrura & 66.5 & 45.4 & & & 2.7 & 72.0 \\
Diaphanosoma excisum & 33.2 & 13.8 & & 11.5 & 2.4 & 16.0 \\
Daphnia barbata & 0.3 & & 74.6 & 40.5 & 81.3 & 12.0 \\
Brachionus patulus & & 13.8 & 4.5 & 15.7 & 2.7 & \\
Keratella tropica & & 13.1 & 5.4 & 19.9 & 6.2 & \\
Filinia opoliensis & & & 10.5 & & 2.1 & \\
Nauplii & & 8.5 & & & & \\
Others & & 5.4 & 5.0 & 12.4 & 2.4 & \\
\hline
\end{tabular}

$16.0 \%$ respectively.

The results exhibited a clear ontogenic shift with lower length groups feeding predominantly on $M$. micrura and $D$. excisum while larger classes feeding mainly on $D$. barbata. $56 \%$ of the lowest length class fed on the smallest prey, M. micrura which averaged $627 \mu \mathrm{m}$ in length while $23.4 \%$ of the class fed on medium sized $D$. excisum with a mean length of $790 \mu \mathrm{m}$. These proportions decreased with increase in size of $O$. niloticus juveniles and in the 10.0-19.9 $\mathrm{cm}$ and $20.0-29.9 \mathrm{~cm}$ length classes the fishes were predominantly feeding on $D$. barbata which is a bigger prey. The mean length of $D$. barbata in the lake was found to be $1347 \mu \mathrm{m}$. It was also evident from the results that the smallest size group of $O$. niloticus had the narrowest spectrum of diet with $M$. micrura being the only selected zooplankton in the diet.

\section{DISCUSSION}

The absence of juveniles of $P$. aethiopicus in the fish catches of Lake Baringo is not unique. Earlier studies in Lake Victoria basin revealed that small sizes of the species are rarely encountered in the open waters of lakes (Graham, 1929; Okedi, 1971; Mosille and Mainoya, 1988). The juveniles of the fish are believed to be found in matted roots of papyrus and may be limited to these habitats (Graham, 1929; Greenwood, 1966). While an earlier investigation in the lake had reported that $P$. aethiopicus show selective preference for fishes as food (Mlewa and Green, 2004), the present study shows that $P$. aethiopicus prefer feeding on molluscan diet. This corroborates the findings of Corbet (1961) in Lake Victoria. P. aethiopicus, which was introduced into Lake Baringo in 1975 and presently dominates the fish community, is mostly a benthic feeder and probably has no competitor. Moreover, while $O$. niloticus feeds by sight in the pelagic zone and is probably affected by the lake's high turbidity, $P$. aethiopicus feeds by groping at the bottom of the lake which molluscs inhabit. The success of $P$. aethiopicus may be as a result of the widespread dis- 
tribution, albeit in low abundance, of molluscs in the lake (Muli et al., 2007).

Like $P$. aethiopicus, $C$. gariepinus also feeds by feeling and as such would be expected not to be affected much by the turbidity of Lake Baringo water. The species probably lacks strong jaws to utilize the available molluscs in the lake. Predation on zooplankton by adult C. gariepinus has also been reported by Dejen et al. (2004) in Lake Tana in Eritrea. The use of zooplankton as food by adult C. gariepinus in Lake Baringo is probably a pointer that the lake lacks alternative larger prey for the fish. Its wide, subterminal mouth enables it to suck in large amounts of water which is flushed through the gills for filter feeding. Efficiency of zooplankton capture is ensured by the large number of gill rakers which increase with size (Bruton, 1977). Dependence on zooplankton by the larger $C$. gariepinus results in competition with small-ler fish and $O$. niloticus which could result in the reduction of forage success. However, being a non-visual filter feeder, it is probable that the fish fed in areas with high density of the prey. In Lake George, Burgis (1973) found high densities of $D$. barbata just above the surface of mud, a habitat they probably also occupy in Lake Baringo.

That cladocerans are favoured, than the more abundant copepods, as prey by fish predators in Lake Baringo corroborates earlier studies. Zaret (1980) and O'Brien (1987) reported that zoopanktivorous fish often take cladocerans in preference to copepods perhaps because the latter have a more erratic mode of motion and are, as such, not easy to capture, a fact that could also explain the results of this study.

$O$. niloticus exhibited a richer floral and faunal dietary assemblage than the other species with algae being utilized in all the length classes. The general low numbers of zooplankton in the stomachs of $O$. niloticus could probably be attributed to turbidity of the lake water (Omondi et al., 2011) which reduces visibility of the predators and on feeding rythms. The lack of clear zooplankton species selectivity pattern could be due to importance of other food items. In the present study, it is suspected that due to the high turbidity, the species could heavily be relying on algal matter which dominated the diet of $O$. niloticus.

\section{Conclusions and recommendations}

The study reveals the importance of algae, mollusks, fish and higher plants as food for fish in Lake Baringo. It further showed that zooplankton forms an important item in the diets of $O$. niloticus and $C$. gariepinus with possible competition for the item, especially between adult $C$. gariepinus and juveniles of $O$. niloticus. The catches of $O$. niloticus, which once dominated Lake Baringo, have declined due to deteriorating water quality especially increasing turbidity. Besides reduction of the euphotic zone, the turbid water also reduces feeding efficiency of the fish which feeds by sight. C. gariepinus in the lake, on the other hand, lack suitable food due to low densities of macroinvertebrates. The fish, particularly the adults, have thus taken to feeding on zooplankton especially $D$. barbata thus competing for prey with its juveniles and other fish species especially $O$. niloticus leading to reduced growth. $P$. aethiopicus which was introduced into the lake has flourished due to occurrence of mollusc in the lake for which there is no competition.

There is need to reduce siltation into the lake by rehabilitation of soil cover in the catchment of Lake Baringo. This would reduce turbidity in the lake with a result of increased productivity due to increased light penetration. Reduced turbidity would also culminate in increased macrophytic community, hence further increase in the lake's productivity. Considering the development projects coming up around the lake, there is also need to control pollution into the lake to prevent eutrophication.

\section{ACKNOWLEDGEMENTS}

The study was funded by National Council of Science and Technology, Kenya (NCST). We are also grateful to Prof. James Njiru for reading and making useful suggestions to improve this paper. Finally, our thanks go to mercantile staff at KMFRI, Baringo who helped in the fish sampling.

\section{REFERENCES}

Abdel-Aziz NE, Gharib SM (2007). Food and feeding habits of round Sardinella (Sardinella aurita) in El- Mex Bay, Alexandria, Egypt. Egypt. J. Aquat. Res. 33: 202-221.

Adeyemi SO, Bankole NO, Adikwu Al (2009). Food and feeding habits of Protopterus annectens (Owen) in Gbedikere Lake, Bassa, Kogi State, Nigeria. Cont. J. Biol. Sci. 2: 7 - 11.

Britton JR, Ng'eno JBK, Lugonzo J, Harper D (2006). Can an introduced, non-indigenous species save the fisheries of Lakes Baringo and Naivasha, Kenya? In Proceedings of the XI World Lake Conference, Nairobi, Kenya, Vol. II, Odada, E. O., Olago, D. O., Ochola, W., Ntiba, M., Wandiga, S., Gichuki, N., Oyieke, H. (eds). ILEC: Tokyo; 568-572.

Bruton MN (1977). The biology of Clarias gariepinus (Burchell, 1822) in Lake Sibaya, Kwazulu with emphasis on the role as a predator. Unpublished. Department of Zoology Institute for Freshwater Studies, Rhodes University.

Burgis MJ (1973). Observations on the Cladocera of Lake George, Uganda. J. Zool. Lond. 170: 339-349.

Busienei W (2003). Habitat characteristics, feeding habits and food preferences by tilapiine fish, Oreochromis niloticus baringoensis (Trewavas, 1983) in turbidity-stressed sites of Lake Baringo. MSc Thesis, Egerton University. pp.117.

Corbet PS (1961). The food of non-cichlid fishes in the Lake Victoria basin, with remarks on their evolution and adaptation to lacustrine conditions. J. Zool. Lond. 37: 197-203.

Dadebo E (2000). Reproductive biology and feeding habits of the catfish Clarias gariepinus Burchell (Pisces: Clariidae) in lake Awassa, Ethiopia. SINET. Ethiop. J. Sci. 23: 231-246.

Dadebo E (2009). Filter feeding habit of the African catfish Clarias gariepinus Burchell, 1822 (Pisces: Clariidae) in Lake Chamo Ethiopia. Ethiop. J. Biol. Sci. 8(1): 15-30.

David DL, Edward A, Adass PA, Jesse C (2010). Some Aspects of water quality and the Biology of Clarias gariepinus in Vimtim stream, Mubi Adamawa State, Nigeria. World J. Fish Mar. Sci. 2(2): 129-133.

Dejen E, Vijverberg J, Nagelkerke LAJ, Sibbing FA (2004). Temporal 
and spatial distribution of microcrustacean zooplankton in relation to turbidity and other environmental factors in a large tropical lake, Lake Tana, Ethiopia. Hydrobiologia 513: 39-49.

El Gamal Ael-R, Ismail NM (2005). Food composition and feeding habits of some fresh water fishes in various water systems at Abbassa, Egypt, with special reference to snails transmitting diseases. J. Egypt. Soc. Parasitol. 35(2):637-52.

Getabu A (1994). A comparative study on the feeding habits of Oreochromis niloticus in Nyanza Gulf, Lake Victoria and sewage ponds. In: proceedings of the Second EEC Regional Seminar on Recent Trends of Research on Lake Victoria Fisheries, Kisumu, Kenya, 25-27 September 1992 (Eds. Okemwa E, Wakwabi E and GETABU A). ICIPE Press, Nairobi, Kenya.

Graham M (1929). The Victoria Nyanza and its Fisheries. A Report of the Fishing Survey of Lake Victoria (1927-28). Crown Agents for the Colonies, London.

Greenwood PH (1966). The Fishes of Uganda. The Uganda Society, Kampala.

Hynes HBN (1950). The food of freshwater sticklebacks (G. aculentus and $P$. pungitius) with a review of methods used in studies of the food of fishes. J. Anim. Ecol. 19: 35-58.

Kallqvist T (1987). Primary production and phytoplankton in Lake Baringo and Lake Naivasha, Kenya. Norwegian institute for water research report. p. 59.

Mlewa CM, Green JM (2004). Biology of the marbled lungfish, Protopterus aethiopicus Heckel, in Lake Baringo, Kenya. Afr. J. Ecol. 42(4): 338-345.

Mosille OIW, Mainoya JR (1988): Reproductive biology of the East African Lungfish (Protopterus aethiopicus) in MwanzaGulf, LakeVictoria. Afr. J. Ecol. 26:149-162.

Muli JR, Omondi R, Owili M, Guya F, Gichuki J, Ikmat P, Ouma H (2007). Spatial variations in water quality, plankton and macroinvertebrates p 7-48. In Muli JR,. Getabu A, Gichuki J, Wakwabi E, Abila R. Lake Baringo Research Expedition (LABRE): Fisheries and Environmental Impact. KMFRI/LABRE Tech. Report 2 p. 109.
Njiru M, Okeyo-Owuor JB, Muchiri M, Cowx IG (2004). Shifts in the food of Nile Tilapia, Oreochromis niloticus (L.) in Lake Victoria, Kenya. Afr. J. Ecol. 42: 163-170.

O'Brien WJ (1987). Planktivoury by fish; thrust and parry in pelagia. pp 3-16. In Predation and indirect effects on aquatic communities W. C. Kerfoot \& ASih (eds), University press of New England, Hanover $\mathrm{HH}$, p. 480.

Okedi J (1971). Maturity, Sex Ratio and Fecundity of the Lungfish (Protopterus aethiopicus Heckel) from Lake Victoria pp.17-20. EAFFRO Annual Report (1970). p.135.

Omondi R, Yasindi AW, Magana AM (2011). Spatial and Temporal Variations of Zooplankton in Relation to Some Environmental Factors in Lake Baringo, Kenya. Eger. J. Sci. Technol. 11: 29-50.

Oniye SJ, Adebote DA, Usman SK, Makpo JK (2006). Some Aspects of the Biology of Protopterus annectens (Owen) in Jachi Dam near Katsina, Katsina State, Nigeria. J. Fish. Aquat. Sci. 1: 136-141.

Pius MO, Benedicta OO (2002). Food and feeding inter-relationship. A preliminary indicator to the formulation of the feed of some Tilapiine fishes. Trop. J. Anim. Sci. 5(1): $35-41$.

Potts WM, Hecht T, Andrew TG (2008). Does reservoir trophic status influence the feeding and growth of the sharptooth catfish, Clarias gariepinus (Teleostei: Clariidae)? Afr. J. Aquat. Sci. 33: 149-156.

Shalloof KAS, Khalifa N (2009). Stomach contents and feeding habits of Oreochromis niloticus (L.) from Abu-Zabal lakes, Egypt. World Appl. Sci. J. 6(1): 1-5.

Skelton P (1993). A Complete Guide to the Freshwater Fishes of Southern Africa. Halfway House: Southern Book Publishers Ltd.

Yalcin S, Akyurt U, Solak K (2001). Stomach Contents of the Catfish (Clarias gariepinus Burchell, 1822) in the River Asi (Turkey). Turk. J. Zool. 25: 461-468.

Yalcin S, Solak K, Akyurt I (2002). Growth of catfish, Clarias gariepinus (Claridae) in River Asi (Orontes), Turkey. Cybium 26(3): 163-172.

Zaret TM (1980). Predation of freshwater communities, Yale University press, New Haven. p.187. 